\title{
PROFESSIONAL EDUCATION IN RUSSIA: ANALYSIS OF PROBLEMS AND PROSPECTS OF PROFESSIONAL STAFF TRAINING
}

\author{
Elena Klimova \\ Department of Psychology of development and education \\ Tsiolkovsky Kaluga State University \\ 26 Stepan Razin str., Kaluga, Russia, 248023 \\ klimovelen@yandex.ru \\ Tatyana Chernisheva \\ Department of philosophies and political science \\ Kaluga branch of Bauman Moscow State Technical University \\ 2 Bazhenov str., Kaluga, Russia, 248600 \\ t.chernyshewa7@yandex.ru
}

\begin{abstract}
As the result of transfer to the market economy and joining Bolognese declaration the system of professional education in Russia undergoes the series of transformations. For optimization of the budget means expenditure there takes place the closing and consolidation of professional educational organizations of all levels that leads to the decrease of education accessibility. Elimination of the primary stage of professional education and introduction of bachelor degree as a stage of the higher professional education leads to the complications in realization of the principle of continuation of professional education. The transfer to the two-step system of higher education faces students with the choice: to remain a bachelor (half-taught specialist) and reduce the own chances for employment or receive the full education, finished it in MA. Orientation of Federal state standards on the competence approach results in the decrease of professional education quality.

To raise the quality of professional staff training in Russia it is important to take the following measures. Firstly, to stop the practice of closing and consolidation of educational organizations, for optimization of the budget means expenditure. Secondly, to eliminate contradictions in realization of the principle of professional education continuity at the expense of return of the primary state of professional education into the system of professional education and of the specialist degree on series of directions into the system of higher education and increase of budget places in MA. Thirdly, to raise the quality of qualified staff training by decrease of the load on teachers, use of improved activity approach at elaboration of Federal state educational standards, orientation of professional education on the formation of integral structure of professional activity in future specialist instead of separate competences, given annually from above.

Keywords: professional education, reformation of education, continuity of education, quality of education, general accessibility of education, Bolognese process, qualified staff.
\end{abstract}

\section{Introduction}

In connection with the transfer of Russia to the market economy and joining Bolognese process the system of education in Russia undergoes the significant transformations. Mane laws and by-laws were accepted for modernization of education. Federal law of Russian Federation of 29 of December, 2012, N 273-FL "On education in Russian Federation" became the integral document that regulates the processes in educational sphere [1].

The system of professional education faced the series of problems at reformation. To find the optimal variants of improvement of professional education system, it is necessary to analyze in details the results of reforms introduction, to reveal constructive and destructive innovations.

\section{Analysis of literary data and statement of problem}

Rather big number of scientific works is devoted to the study of reformation of educational system, connected with acceptance of Bolognese declaration and Lisbon strategy. The foreign and Russian authors consider the different aspects of realization of the new educational system. The general discussion about philosophical, organizational-managerial aspects, mechanisms of adjust- 
ment of the higher education system to the principles of level organization and other takes place [2]. Transformation of European systems of higher education takes place with the different speed and different effectiveness [3]. At reformation the social demands to the quality of higher education renewed, the principles of HEI financing and their autonomy changed [4]. The following instruments of modernization of the higher education are considered: widening of institutional autonomy of educational institutions, increase of private investment in the sphere of higher education, partnership between the higher educational institutions and industrial enterprises, widening of mobility of students and stuff [5]. Bolognese process is an example of the fact that "the changes and continuity can be two sides of one coin" [6].

At the transfer of Russian professional education to Bolognese system the series of problem were faced. The quality of professional education decreases: the standards of higher professional education in Russia do not correspond to the speed of socio-economic development of the country [7]. For today the criteria of quality and effectiveness of educational services are elaborated, the measures on increase of higher education quality are tested and the factors of raise of economic effectiveness of educational market regulation are studied [8]. The question about insufficient financing of education is urgent. In consolidated budget of Russian Federation for 2014 the share of costs on education was 4,3\% of GDP. In 2016 its decrease to 3,9\% was planned. In USSR in 1950 it was $10-12 \%$. In the result of reduction of the state expenditures on education its quality and accessibility suffer [9].

\section{Aim and tasks of research}

The aim of the work is to analyze the results of reformation of professional education in Russia, to consider the problems and prospects of the qualified staff training.

For attaining the set aim the following tasks were set:

1. To analyze the problems that the professional education faced with as the result of transfer to the market economy and joining Bolognese declaration.

2. To consider the factors, which favor the increase of the quality of qualified staff training in Russia.

\section{Results of research}

As the result of transfer to the market economy and joining Bolognese declaration the system of professional education in Russia faced the series of problems. Firstly, in the result of optimization of the state educational organizations for saving of budget means there is observed the decrease of professional education accessibility. Secondly, the contradictions in realization of continuity principle appeared. Thirdly, the quality of qualified staff training decreased.

Let's stop on each problem more detail.

During several years the active discussion on the problem "Education it is a right or service?" took place. The result of general discussion was an inclusion in the new Federal law of 29 of December, 2012 N 273 "On education in Russian Federation" of the point, according to which, "The main tasks of legal regulation of relations in educational sphere are: 1) support and defense of constitutional right of the citizens of Russian Federation for education..." (point 1 Article 4 of Law [1]).

Constitution of RF says:

"1. Everyone has a right for education.

2. General accessible and free of charge pre-school, basic general and secondary professional education in the state or municipal educational institutions and on enterprises is guaranteed.

3. Everyone has a right to receive the higher education in state or municipal educational institution and on enterprise on the competitive base free..." (point 1-3 Article 43 of Constitution of RF [10]).

Let's analyze, how the state guarantees the right of citizens for generally accessible and free professional education.

The node problem of the modern educational policy is optimization of the state expenditures on education for the saving of budget means. "The share of expenditures on education in gross do- 
mestic product of USSR in 1950 years was 10-12\%; in $1970-7 \%$; in consolidated budget of 2014 it is $4,3 \%$, in 2016 it must decrease to $3,9 \%$ \% [9].

Optimization leads to the closing or consolidation of professional educational organizations of all levels. Particularly, according to the data of Federal service of the state statistics, the number of educational institutions of the primary professional education (PPE) from 1990 to 2011 year decrease in two times, from 4328 to 2040 [11] (Fig. 1).

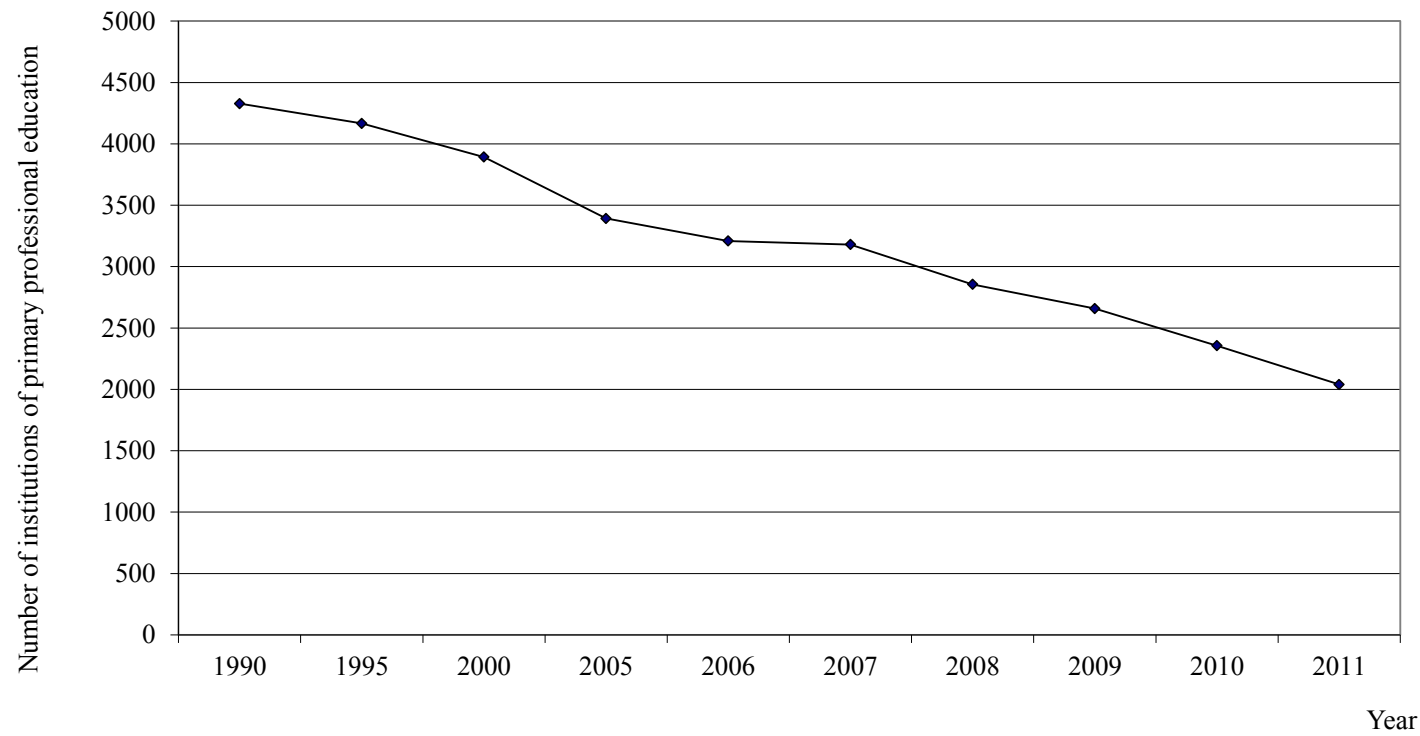

Fig. 1. Number of institutions of primary professional education from 1990 to 2011

The similar picture is typical also for the secondary professional education (SPE). The number of professional educational organizations that train the qualified workers decreased from 1990 to 2014 in four times, from 4328 to 1007 [12, p. 200] (Fig. 2).

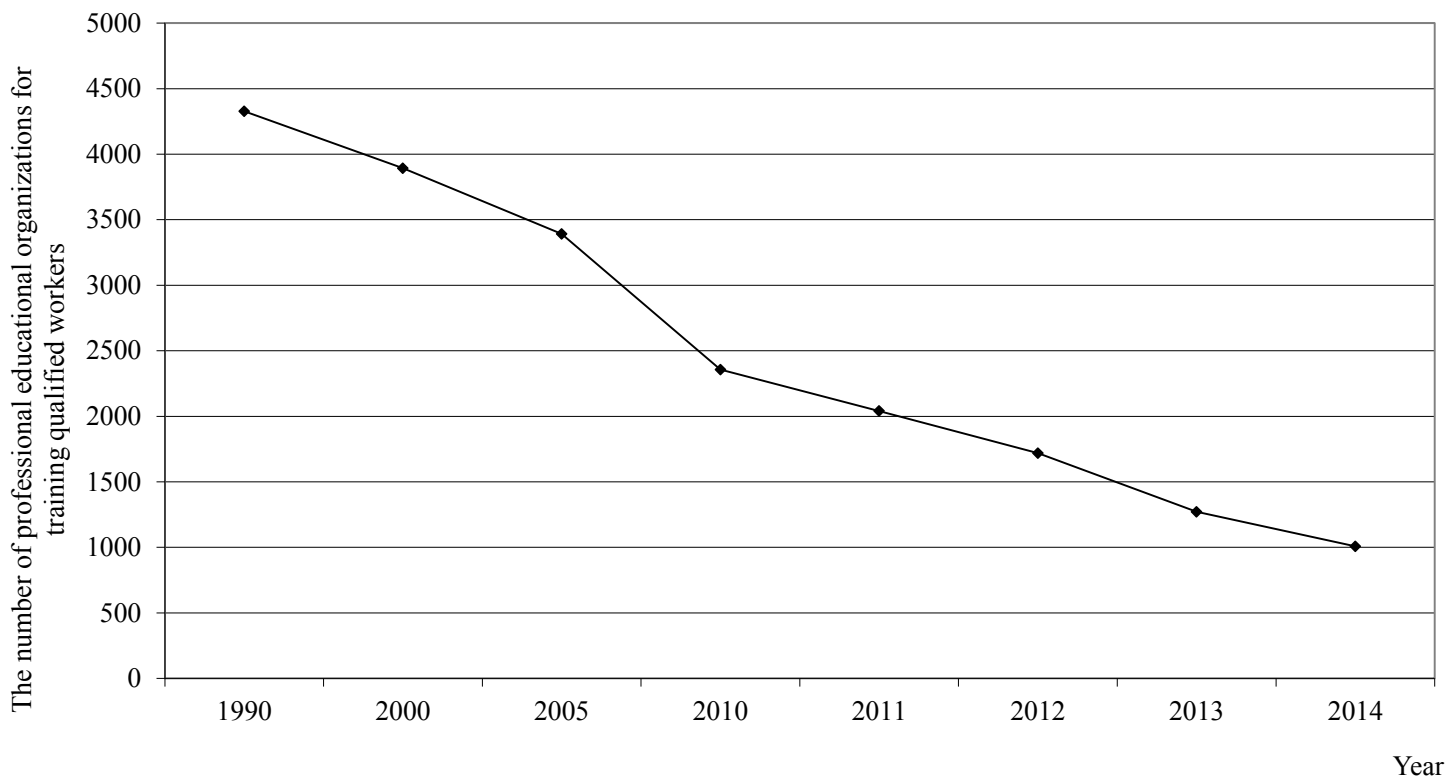

Fig. 2. The number of SPE professional educational organizations that train the qualified workers from 1990 to 2014

Rather other picture is observed with institutions of the secondary professional education that prepare the secondary specialists. The number of SPE professional organizations that train the 
secondary specialists changed wavy from 1990 to 2014. From 1990/91 to 2005/06 and from 2010/11 to $2012 / 13$ there was observed the growth of SPE institutions number. In last recent years after the abrupt decline in 2013/14 the increase of their number was fixed by 2014/2015 school year [12] (Fig. 3).

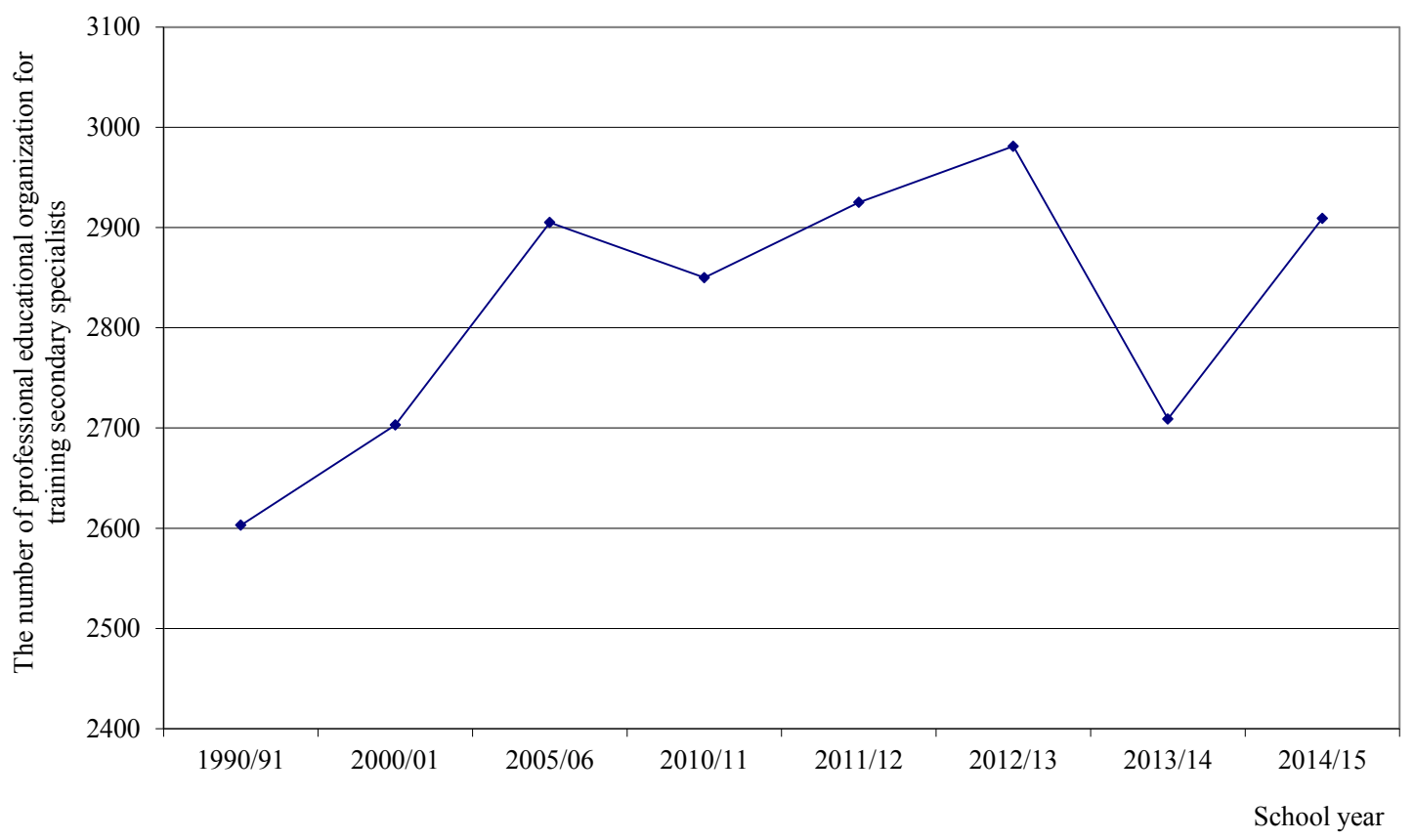

Fig. 3. The number of SSE professional educational organization for training secondary specialists from 1990/91 to 2014/15 school years (for the beginning of school year)

The tendency to decrease of educational institutions is traced also in the sphere of higher professional education (see Fig. 4). According to the data of Federal service of the sate statistics, the number of all higher professional educational institutions decreased from 2008/09 school year to $2014 / 15$ one from 1134 to 950 , that is 184 HEI were closed [12].

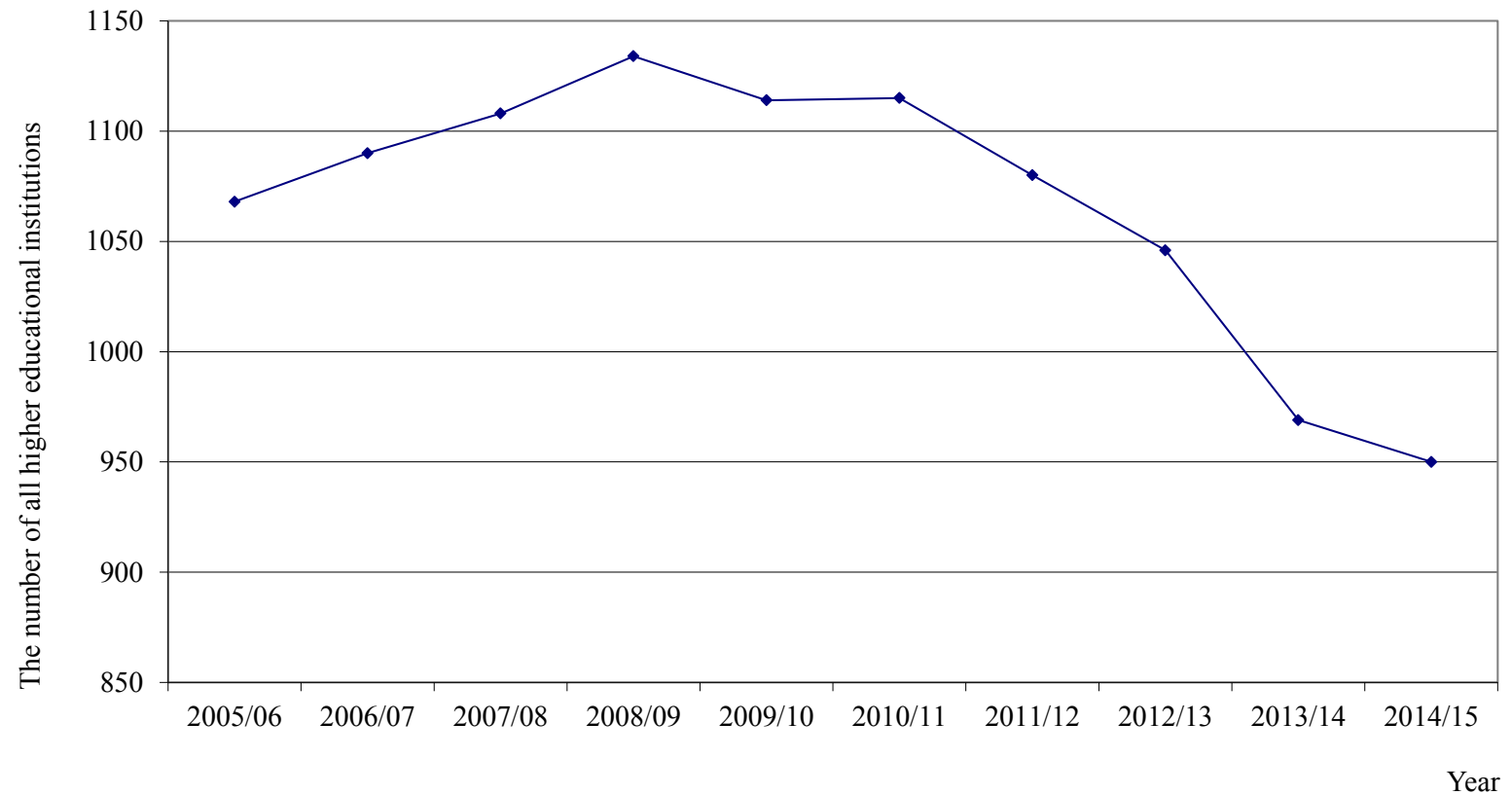

Fig. 4. The number of all higher educational institutions from $2005 / 2006$ to $2014 / 2015$ school year 
According to the "Conception" of federal objective program of education development for 2016-2020 in the nearest five years it is planned to eliminate or reorganize $40 \%$ of Russian HEI and $80 \%$ of branches [13].

Optimization of expenditures leads also to the reduction of budget places in the professional educational institutions. The high speed of reduction of the HEI number and the number of budget places in them can lead in a short time to the lack of places in the higher educational institutions.

According to data of Russian statistics, for 2014 year [14] only 31,5\% of able-bodied population of RF had the higher education. Introduction of the new Federal law № 273 "On education in Russian Federation" leads to the reduction of the number free budget places. "The law provides the refusal of existing point, according to which, it must be 170 budget students for 10 thousands of population, and the replacement of it with the new one: 800 students for 10 thousand of youth 17-30 years old... The calculations testify: at existing approach the number of budget students in the country will reduce no less than by 700 thousand till 2020. And in calculation for 10 thousand of population it is approximately from 172 to 125 . Near $40 \%$ of students study free of charge in Russia, whereas in France- more than 80 \%, in Germany - more than 90 \%. We do not mention Soviet Union, where all students studied free of charge. So, the calculation of the necessary number of budget places must be led not from the number of school graduates, but from the general number of people, who need the higher education. Then it would be found out that in 2011-2012 school year $2 \mathrm{mln} 460$ thousands students in Russia of the general number $6 \mathrm{mln} 490$ thousand or approximately $38 \%$ studied free of charge" [9].

The general level of social development, degree of scientific-technical progress, cultural level of the country is determined by the number of people with high-quality higher education. It allows person to develop comprehensively, to reveal the own potential more fully, to be a competitive actor on the labor market and so on. The deprivation of human of the possibility to improve during the whole life leads to the stop in its development and finally in stagnation of the whole society.

The second most important problem of professional education is a presence of contradictions in realization of the continuity principle. From the one side, Federal law N 273 «On education in Russian Federation" indicates the necessity of state guaranteeing of the possibility to receive education during the whole life (continuous education) (point 2 Article 10 of Law) [1]. From the other side the primary stage of professional education is absent in this Law:

1) secondary professional education;

2) higher education - bachelor degree;

3) higher education - specialist, master degree;

4) higher education - training of highly qualified staff [1] (point 5 Article 10 of Law). According to the Law, the primary professional education was included in the structure of secondary professional education on the programs of qualified workers (employees) training [1] (Article 108 of Law).

Elimination of the primary stage of professional education leads, in particular, to the complications in the system of specialists training of in the spheres of culture and art. The training of specialist in this field provides the successive mastering of the professional training levels: PPE-SPE-HPE or "child school of arts-college-HEI". The child school of arts is an important stage of professional education in this sphere.

The inclusion of PPE in HPE also leads to the disturbance of education continuity principle for persons, who have complications in the mastering of secondary education program. It especially concerns the ones with limited health possibilities and difficult life situation. For example, disabled people, who did not receive the primary professional skills, can not find a job, being transformed into socially unclaimed members of society, in citizens, who are beyond the poverty line. The students with difficult life situation have not a possibility to receive profession and direct their energy in destructive channel, make illegal actions and fill up the community homes.

The saving of state budget on the primary and secondary professional education is transformed for the state into the great expenditures on the keeping of delinquent teenagers in confinement institutions. "Audit of effectiveness of the use of the federal budget means on realization of the "Conception of development of criminal-executive system of Russian Federation to 2020" as to reformation of community homes" in 2011-2013 demonstrated that "the average annual ex- 
penditures for one pupil in community home is more than $1,5 \mathrm{mln}$ rubles and for one children in orphanage $-689,5$ thousands rubles"[15].

The positive influence of education on criminality decrease was demonstrated by the modern American businessman Harris Rozen, who paid the study in college for all school graduates of the poor district of Florida and the kindergarten and nursery - for all preschool children. In the result the number of young people, who finished school in this district, increased from $25 \%$ to $100 \%$, and criminality level decreased twice.

Elimination of the primary stage of professional education and reduction of the number of secondary professional educational institutions that are the forge of workers-specialists is not agreed with the need of modern society in qualified working staff, impede the successful socioeconomic development of the country.

The third serious problem of the modern professional education is the decrease of qualified staff training quality. It is conditioned by the series of causes, both formal and content ones. Let's stop on several ones.

The one of formal cases that decreases the education quality is the growth of the number of students for one pedagogical worker at all stages of professional education. The annual increase of students' number in calculation for one pedagogical worker in existing "road map" of education is fixed: in the system of secondary professional education and professional study from 12,7 (2012) to 14,8 (2018), in the system of higher education - from 9,4 (2012 ) to 12 persons (2018) [16]. For comparison, the load on the worker of pedagogical staff of the higher school in 1992 was 7 students for one teacher.

The increase of students' number for one education worker leads to the reduction of pedagogical workers' number, increase of students' number in groups, growth of the load on the teacher, worsening of education quality that is contradict the optimization principle: "improve of the one parameters if the other ones did not worsen" (Pareto optimum).

The other formal cause that reduces the professional education quality is the transfer to the two-stage system of higher education that faced students with the choice: to remain bachelor (halftaught specialist) or receive the full education in MA.

According to the data of Superjob recruiting agency, received at the study of 1000 native companies [17], less than half of companies (43\%) at admission to work consider candidates with bachelor degree on a pair with the contenders, who have the full higher education and specialist qualification, $35 \%$ of respondents compared bachelors with contenders that have incomplete higher education motivating that, for example, as following: "These categories of citizens have the general notion about received profession and no concrete specialization"; "Bachelor it is halfmade specialist, not especially wanted in technical branches. The secondary special education is more advantageous here. In humanitarian field they may have chances"; "I have both bachelor and master degree. I can say honestly, that bachelor it is, unfortunately, half-educated person: there is no the necessary deep knowledge". $8 \%$ of interrogated compared bachelors to the graduates of TS, $14 \%$ - had difficulties with answer.

Pedagogical education in particular suffered a lot from introduction of the bachelor degree. It is not clear for today, who is the teacher-bachelor, what a difference between his/her competences and the ones of the teacher with secondary special education. The bachelor learning pedagogical programs (especially, applied ones) practically double the ones for the teacher, who receives specialty in college. Thus, the graduate of pedagogical college, who enter to the applied bachelor course, receives, in fact, the secondary special education one more time.

The problem is also the transfer of bachelors to the second stage of the higher education - MA course. Firstly, the number of free of charge places in MA is much less than in baccalaureate. Secondly, the tuition fee in very high in MA. Thirdly, many HEI have not MA on several specialties.

To the causes of the content type that lead to the decrease of professional education quality can be related the introduction of competence approach in Federal state educational standards. In the competence approach specialist is considered as the owner of heterogenic competences (generally cultural, generally professional, specially-professional) as opposite to the native (activity) approach that considers specialist as a subject of professional activity. The requirements to the 
generally cultural, generally professional, specially-professional are also in the activity paradigm but the other principle of the study organization is typical for it. The future specialist forms fundamental, system thinking, integral notion about the future professional activity and scientific world image in whole. At professional learning student masters the node actions of professional activity, acquiring the certain qualification, in fact, professional competence that is the level of human readiness to the one or another type of labor.

From our point of view the prospective direction of the development of modern professional education is not the introduction of competence approach but the improvement of activity (personal-activity) one: its orientation not only on the formation of operational-technical side of the specialist's activity but also of the development of intentional (motivational-objective) side of activity.

The scientific research, carried out on the sampling of entrepreneurs, demonstrated that the success in business activity is achieved only by the specialist, in whom the all elements of professional business activity are formed (business motives, purposes, node actions and personal resources) [18]. Successful entrepreneurs demonstrated both objective parameters of success (stably high productivity in the work) and subjective ones (feeling of satisfaction from activity realization). In unsuccessful entrepreneurs were absent both objective and subjective success parameters. Productive (relatively successful) entrepreneurs had the high objective and low subjective success parameters for the moment of research. The repeated study of activity of productive entrepreneurs in 10 years demonstrated that most of them passed to the category of unsuccessful specialists.

At orientation of professional education on the formation of integral structure of professional activity in future specialist [19] professional educational organization would train the highly qualified graduate specialists, able to realize their professional activity successfully, to improve professionally and personally, adapt to the changing conditions of reality.

\section{Conclusions}

The analysis of current professional education in Russia demonstrated that as the result of transfer to the market economy saving and joining Bolognese declaration the professional education faced the series of problems: reduction of its general accessibility, disturbance of continuity principle of professional education, decrease of the quality of qualified staff training.

To raise the quality of qualified staff training in Russia it is necessary: firstly, to raise the accessibility of professional education for satisfying the need of Russian society in highly qualified staff, cultural and socio-economic development, support of the socio-psychological stability in the country. Secondly, to eliminate the contradiction in realization of the continuity principle of professional education at the expense of return of the primary professional education in the system of professional education and the specialist degree on the series of directions in the system of higher education, raise of MA accessibility for bachelors. Thirdly, to raise the quality of the qualified staff training at the expense of decrease of the load on teachers, use of improved activity approach at the elaboration of Federal state educational standards.

\section{References}

[1] Federal'nyj zakon Rossijskoj Federacii № 273-FZ “Ob obrazovanii v Rossijskoj Federacii” (2012). Rossijskaja gazeta, 5976.

[2] Telegina, G., Schwengel, H. (2012). The Bologna Process: perspectives and implications for the Russian university. European Journal of Education, 47 (1), 37-49. doi: 10.1111/j.1465-3435.2011.01506.x

[3] Elken, M., Gornitzka, Å., Maassen, P., Vukasovic, M. (2011). European Integration and the Transformation of Higher Education. Oslo: University of Oslo, 57.

[4] Gornitzka, Å. (2010). Bologna in Context: a horizontal perspective on the dynamics of governance sites for a Europe of Knowledge. European Journal of Education, 45 (4), 535-548. doi: 10.1111/j.14653435.2010.01452.x

[5] Maassen, P., Stensaker, B. (2010). The knowledge triangle, European higher education policy logics and policy implications. Higher Education, 61 (6), 757-769. doi: 10.1007/s10734-010-9360-4

[6] Serrano-Velarde, K., Stensaker, B. (2010). Bologna - Realising Old or New Ideals of Quality? High Educ Policy, 23 (S2), 213-226. doi: 10.1057/hep.2010.1 
[7] Benin, V. L. (2015). The Place of Education in Modernization Processes. Russian Education \& Society, 57 (2), 106-118. doi: 10.1080/10609393.2015.1018743

[8] Kalinushkina, V. A. (2015). Formirovanie mehanizma povyshenija jeffektivnosti i kachestva obrazovatel'nyh uslug vysshej shkoly v uslovijah reformirovanija sistemy rossijskogo obrazovanija. SaintPeterburg, 198.

[9] Smolin, O. N. (2015). Vysshee obrazovanie: bor'ba za kachestvo ili pokushenie na chelovecheskij potencial? Sociologicheskie issledovanija, 7, 30-37.

[10] Konstitucija Rossijskoj Federacii (2013). Moscow: Os', 89.

[11] Obrazovatel'nye uchrezhdenija nachal'nogo professional'nogo obrazovanija (2013). Oficial'nyj sajt Federal'noj sluzhby gosudarstvennoj statistiki. Available at: http://www.gks.ru/free_doc/new_site/population/obraz/np-obrl.htm

[12] Rossijskij statisticheskij ezhegodnik (2015). Moscow, 728.

[13] Rasporjazhenie Pravitel’stva RF № 2765-r «Koncepcija federal'noj celevoj programmy razvitija obrazovanija na 2016-2020 gg.» (2014). Available at: http://government.ru/media/files/mlorxfXbbCk.pdf

[14] Trud i zanjatost' v Rossii (2015). Moscow, 274.

[15] Tjuremnyj portal Rossii. Available at: http://prisonlife.ru/analitika/2947-reformirovanie-vospitatelnyh-koloniy-dlya-nesovershennoletnih-nuzhno-priznat-necelesoobraznym.html

[16] Rasporjazhenie Pravitel'stva Rossijskoj Federacii ot 30 aprelja 2014 g. №722-r “Plan meroprijatij ("dorozhnaja karta") "Izmenenija v otrasljah social'noj sfery, napravlennye na povyshenie jeffektivnosti obrazovanija i nauki” (2014). Rossijskaja gazeta. Internet-portal. Available at: http://www.rg.ru/2014/05/08/ nauka-site-dok.html

[17] $43 \%$ rabotodatelej bakalavrov ot magistrov ne otlichaet (2009). Superjob. Available at: https:// www.superjob.ru/community/otdel_kadrov/39958

[18] Klimova, E. K. (2014). Professional'naja dejatel'nost' predprinimatelja. Psihologija uspeha. Saint Peterburg: Izdatel'sko-Torgovyj Dom «Skifija», 208.

[19] Klimova E. K., Pomazina O. A. (2016). Psihologija uspeha. Praktikum po samorazvitiju lichnosti. Saint Peterburg: Rech', 240. 